\author{
dr Patrycja CHODNICKA-JAWORSKA \\ Wydział Zarządzania, Uniwersytet Warszawski \\ e-mail: pchodnicka@wz.uw.edu.pl
}

DOI: $10.15290 /$ ose.2016.06.84.03

\title{
KONDYCJA FINANSOWA SEKTORA BANKOWEGO JAKO DETERMINANTA RATINGÓW KREDYTOWYCH BANKÓW
}

\begin{abstract}
Streszczenie
Celem artykułu jest analiza wpływu kondycji sektora bankowego na ratingi kredytowe banków. W pracy dokonano przeglądu literaturowego i porównano metodologie stosowane przez Standard\&Poor's (S\&P) oraz Moody's. Na tej podstawie postawiono hipotezę, iż rozwinięty, stabilny i efektywny sektor bankowy pozytywnie oddziałuje na credit rating nadawany poszczególnym bankom. Dane pozyskano z baz Thomson Reuters oraz Banku Światowego. Jako zmienna zależną wykorzystano długoterminowe ratingi kredytowe nadawane bankom przez S\&Pi Moody's. Analizę wykonano na danych rocznych dla lat 2005-2015. W badaniach posłużono się modelem regresji panelowej.
\end{abstract}

Słowa kluczowe: efektywność, rating kredytowy, sektor bankowy

\section{FINANCIAL CONDITION OF BANKING SECTOR AS DETERMINANT OF BANK CREDIT RATINGS}

\section{Summary}

The aim of the paper is to analyse the impact of the financial condition of the banking sector on bank credit ratings. The research involves a literature review and a comparison of the methodologies used by S\&P and Moody's. On this basis, a hypothesis is proposed that a developed, stable and efficient banking sector has a positive effect on credit ratings assigned to individual banks. The data used in the study have been collected from the Thomson Reuters and the World Bank. Long-term issuer credit ratings assigned by S\&P and Moody's are used as the dependent variable. The analysis is performed on annual data for the years 2005-2015. The study uses panel data models.

Key words: efficiency, credit rating, banking sector

JEL: G21, G24, C23

\section{Wstęp}

Agencje ratingowe to podmioty, których głównym celem jest ocena emitenta i proponowanych przez niego instrumentów finansowych pod względem ryzyka upadłości. 
Wśród kilkudziesięciu agencji ratingowych funkcjonujących na świecie prym wiodą trzy największe, do których należą: Standard \&Poor's (S\&P), Moody i Fitch. Wspomniane podmioty popularnie są nazywane „Wielką Trójką”. Aktualnie ich łączny udział w rynku w krajach Unii Europejskiej wynosi ponad 90\%. Publikowane przez nie informacje staja się kluczowymi pod względem: zmian cen akcji, kursów walutowych, cen obligacji, spreadów na CDS i rynkowych stóp procentowych. W związu z tym istotne staje się pytanie, jakie czynniki wspomniane podmioty biora pod uwagę przy ocenie emitenta. W praktyce można je podzielić na te związane z: ryzykiem kraju, ryzykiem sektora oraz samego ocenianego podmiotu. W niniejszym artykule postanowiono zweryfikować, jak kondycja finansowa sektora bankowego oddziałuje na noty nadawane bankom przez agencje ratingowe. Stąd postawiono następująca hipotezę badawczą: rozwinięty, stabilny i efektywny sektor bankowy pozytywnie oddziałuje na credit rating nadawany poszczególnym bankom. Badanie przeprowadzono dzięki wykorzystaniu metod regresji panelowej na danych rocznych dla lat 2005-2015. Z dostępnej autorce wiedzy wynika, że badanie na ten temat nie było dotychczas przeprowadzane.

Artykuł składa się z czterech rozdziałów. W pierwszym przedstawiono metodologię oceny ratingowej banków zaproponowana przez dwie największe agencje ratingowe, a mianowicie S\&P i Moody. Następnie dokonano przeglądu literaturowego. W rozdziale trzecim opisano zastosowaną metodologię oraz dane wykorzystane do badania. W części czwartej scharakteryzowano wyniki, które zakończono wnioskami.

\section{Metodologia oceny ryzyka stosowana przez agencje ratingowe}

\subsection{Moody's Investor Service}

Moody's Investor Service jest jedną z największych agencji ratingowych na świecie. Swoją analizę przeprowadza dzięki zastosowaniu modeli scroingowych. Podczas oceny ryzyka bada następujące aspekty:

- $\quad$ ocena banku przy użyciu metody podstawowego wskaźnika (BCA). Przedstawia ona opinię na temat prawdopodobieństwa upadłości banku w przypadku braku wsparcia z zewnątrz;

- ocena wsparcia z instytucji powiązanych kapitałowo, skorygowana BCA;

- analiza „straty z tytułu upadłości” (ang. lossgivenfailure - LGF);

- ocena możliwości wsparcia rządowego w celu ustalenia ostatecznego ratingu kredytowego dla każdego ocenianego instrumentu, a także oceny ryzyka kontrahenta [Rating Methodology..., 2016].

Do analizy wykorzystuje się dane historyczne, są badane trendy i prognozowane zmiany w przyszłości. Badaniu poddaje się trzy grupy czynników, a mianowicie: profil makroekonomiczny, wskaźniki finansowe i wskaźniki jakościowe. W efekcie powstaje profil ryzyka banku. Na potrzeby pracy skupiono się na analizie profilu makroekonomicznego banków. W poniższej tabeli zaprezentowano wynikową analizy. 
TABELA 1.

Przykładowy makroprofil banku

\begin{tabular}{|c|c|c|c|}
\hline Wskaźniki oceny ratingowej & $\begin{array}{c}\text { Wagi sub- } \\
\text { wskaźników }\end{array}$ & Wartość & Scoring \\
\hline \multicolumn{3}{|l|}{ Czynnik 1. Siła ekonomiczna } & VH+ \\
\hline Dynamika wzrostu & $50 \%$ & VH- & \\
\hline Przeciętna realna stopa wzrostu PKB (2009-2018F) & & 2,7 & \\
\hline $\begin{array}{l}\text { Zmienność przeciętnej realnej stopy wzrostu PKB } \\
\text { (odchylenie standardowe, } 2004 \text {-2013) }\end{array}$ & & 0,9 & \\
\hline WEF Wskaźnik Globalnej Konkurencyjności (2013) & & 5,1 & \\
\hline Wielkość gospodarki & $25 \%$ & $\mathrm{VH}+$ & \\
\hline Nominalne PKB (USD, 2013) & & 1502 & \\
\hline Dochód narodowy & $25 \%$ & $\mathrm{VH}+$ & \\
\hline PKB per capita (PPP, USD, 2013) & & 45138 & \\
\hline \multicolumn{3}{|l|}{ Czynnik 2. Siła instytucjonalna } & VH+ \\
\hline Siła instytucjonalna i efektywność & $75 \%$ & $\mathrm{VH}+$ & \\
\hline $\begin{array}{l}\text { Wskaźnik efektywności rządu Banku Światowego } \\
(2012)\end{array}$ & & 1,62 & \\
\hline Wskaźnik praworządności Banku Światowego (2012) & & 1,75 & \\
\hline Wskaźnik kontroli korupcji Banku Światowego (2012) & & 1,76 & \\
\hline Wiarygodność i efektywność polityki & $25 \%$ & $\mathrm{VH}+$ & \\
\hline Poziom inflacji (w \%, 2009-2018F) & & 2,46 & \\
\hline $\begin{array}{l}\text { Zmienność poziomu inflacji (odchylenie stan- } \\
\text { dardowe, 2004-2013) }\end{array}$ & & 0,81 & \\
\hline \multicolumn{3}{|c|}{ Czynnik 3. Podatność na ryzyko wystąpienia niekorzystnych zdarzeń } & L+ \\
\hline \multicolumn{4}{|c|}{\begin{tabular}{|l|l|l} 
Ryzyko polityczne & & \\
\end{tabular}} \\
\hline \multicolumn{4}{|l|}{ Ryzyko płynności rządu } \\
\hline \multicolumn{4}{|l|}{ Ryzyko luki zewnętrznej } \\
\hline \multicolumn{4}{|l|}{ Ryzyko kraju bankuVS } \\
\hline \multicolumn{4}{|l|}{ Warunki kredytowe } \\
\hline Kredyty sektora prywatnego/PKB & $70 \%$ & 126 & 0 \\
\hline $\begin{array}{l}\text { Trzyletnia zmiana w kredytach sektora prywatne- } \\
\text { go/ PKB (PP) }\end{array}$ & $30 \%$ & $-0,2$ & \\
\hline \multicolumn{4}{|c|}{$\begin{array}{l}\text { Makroprofil sektora bankowego przed wprowadzeniem korekt finansowych } \\
\text { i branżowych VS }\end{array}$} \\
\hline \multicolumn{3}{|l|}{ Warunki finansowania } & -1 \\
\hline \multicolumn{3}{|l|}{ Struktura } & 1 \\
\hline
\end{tabular}

Źródło: [Rating Methodology..., 2016]. 
Jak zostało wcześniej wspominane, Moody's do swojej oceny wykorzystuje macierze scoringowe. Prowadząc analizę, stosuje skalę piętnastopunktową nadając noty od bardzo wysokiej (VH+) do bardzo niskiej (VL-). Podczas badania makroprofilu banku są analizowane trzy grupy czynników, a mianowicie: siła ekonomiczna, siła instytucjonalna i podatność na ryzyko wystapienia niekorzystnych zdarzeń. Wskaźniki przyjęte do analizy wraz z przedziałami klasyfikującymi do poszczególnych grup zostały zaprezentowane $\mathrm{w}$ tabeli 2. Większość $\mathrm{z}$ badanych parametrów pochodzi z baz danych Banku Światowego. Na podstawie zależności zaprezentowanych w tabeli są tworzone macierze scoringowe, weryfikujące zwiazki pomiędzy wskaźnikami ekonomicznymi i poziomem siły instytucjonalnej, w efekcie czego powstaje scoring odporności gospodarczej a podatności na ryzyko wystapienia niekorzystnych zdarzeń.

W rezultacie powstaje miara ryzyka kraju, na obszarze którego działa bank. Wśród wskaźników podatności na ryzyko wystapienia niekorzystnych zdarzeń znajdują się: miary stabilności, wielkości i luki finansowania sektora bankowego. W zaistniałej sytuacji można domniemywać, że kondycja sektora bankowego odgrywa kluczową rolę w ocenie banku.

Następna grupą wskaźników są wskaźniki warunków kredytowych oferowanych przez sektor bankowy. Wśród sub-wskaźników należy wyróżnić:

- $\quad$ stosunek wartości kredytów udzielonych sektorowi prywatnemu do PKB;

- $\quad$ trzyletnią zmianę w poziomie kredytów udzielonych sektorowi prywatnemu do PKB.

Pierwsza z wymienionych determinant jest podstawową miarą dźwigni. Tak jak poprzednio, aby zbadać wpływ analizowanej zmiennej na ocenę ratingowa, wykorzystuje się metodę scoringowa, przy piętnastopunktowej skali, gdzie 1 wskazuje na najniższy, a 15 na najwyższy poziom ryzyka.

Zastosowanie wskaźnika poziomu kredytów udzielonych sektorowi prywatnemu do PKB stanowi miernik stanu kredytów w gospodarce. Wyższy poziom zadłużenia jest naturalną konsekwencją rozwoju finansowego gospodarki, a tym samym może być bardziej zrównoważony w odniesieniu do rozwiniętych gospodarek. Badanie trzyletnich zmian analizowanej zmiennej pomaga określić poziom odchyleń. W literaturze utożsamia się je z większą skłonnością do podejmowania ryzyka, co z kolei może poprzedzać kryzys. W tabeli 2. przedstawiono macierz scoringową badanych zmiennych. 


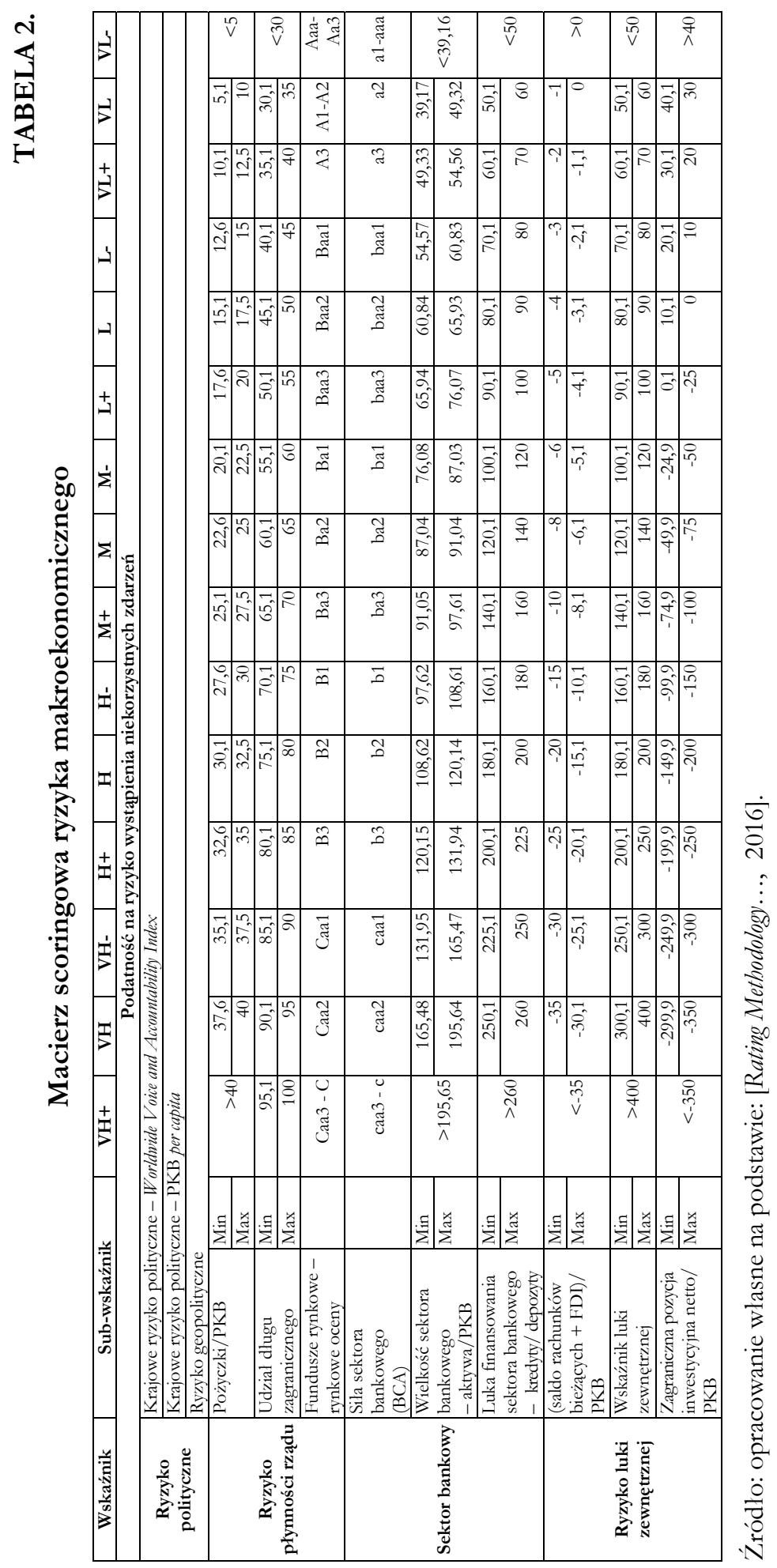


TABELA 3.

Analiza scoringowa warunków kredytowych kraju

\begin{tabular}{|c|c|c|c|c|}
\hline \multirow[t]{2}{*}{ Skala } & \multicolumn{2}{|c|}{$\begin{array}{c}\text { Wskaźnik kredytów udzielonych } \\
\text { sektorowi prywatnemu do PKB } \\
(70 \%)\end{array}$} & \multicolumn{2}{|c|}{$\begin{array}{c}\text { Zmiana w poziomie kredytów udzielo- } \\
\text { nych sektorowi prywatnemu do PKB } \\
(30 \%)\end{array}$} \\
\hline & Min & Max & Min & Max \\
\hline $\mathrm{VH}+$ & \multicolumn{2}{|c|}{$<20$} & \multicolumn{2}{|c|}{$<-30$} \\
\hline $\mathrm{VH}$ & 20 & 25 & -30 & -20 \\
\hline VH- & 25,01 & 30 & $-19,99$ & -10 \\
\hline $\mathrm{H}+$ & 30,01 & 35 & $-9,99$ & -8 \\
\hline $\mathrm{H}$ & 35,01 & 40 & $-7,99$ & -5 \\
\hline $\mathrm{H}-$ & 40,01 & 50 & $-4,99$ & -3 \\
\hline $\mathrm{M}+$ & 50,01 & 60 & $-2,99$ & 0 \\
\hline $\mathrm{M}$ & 60,01 & 75 & 0,01 & 3 \\
\hline M- & 75,01 & 100 & 3,01 & 5 \\
\hline $\mathrm{L}+$ & 100,01 & 125 & 5,01 & 8 \\
\hline $\mathrm{L}$ & 125,01 & 150 & 8,01 & 10 \\
\hline L- & 150,01 & 175 & 10,01 & 15 \\
\hline VL+ & 175,01 & 200 & 15,01 & 20 \\
\hline $\mathrm{VL}$ & 200,01 & 400 & 20,01 & 30 \\
\hline VL- & \multicolumn{2}{|c|}{$>400$} & \multicolumn{2}{|c|}{$>30$} \\
\hline
\end{tabular}

Źródło: opracowanie własne na podstawie: [Rating Methodology..., 2016].

Na podstawie analizy scoringowej warunków kredytowych kraju jest tworzona macierz scoringowa pomiędzy zmianami analizowanych zależności. Efekt stanowi macierz zaprezentowana w tabeli 4.

Kolejnym elementem oceny są wskaźniki warunków finansowania określone za pomocą następujących czynników:

- cena pieniądza na rynku - mierzona na przykład różnicą między stopą oprocentowania kredytu bankowego (LIBOR) i swapu (OIS);

- $\quad$ wartość aktywów banku centralnego.

Strukturę rynku mierzy się indeksem Herfindahla-Hirschmana oraz wskaźnikiem aktywów pięciu największych banków do łącznych aktywów sektora. 
TABELA 4.

Macierz zależności pomiędzy poziomem kredytów udzielanych sektorowi prywatnemu do PKB a jego zmianą

\begin{tabular}{|c|c|c|c|c|c|c|c|c|c|c|c|c|c|c|c|c|}
\hline & \multicolumn{16}{|c|}{ Zmiana w poziomie kredytów udzielonych sektorowi prywatnemu do PKB (30\%) } \\
\hline \multirow{6}{*}{ 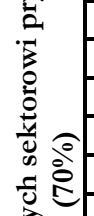 } & & 1 & 2 & 3 & 4 & 5 & 6 & 7 & 8 & 9 & 10 & 11 & 12 & $\overline{13}$ & 14 & 15 \\
\hline & 1 & 1 & 1 & 1 & 1 & 1 & 1 & 1 & 1 & 1 & 1 & 1 & 1 & 1 & 1 & 1 \\
\hline & 2 & 1 & 1 & 1 & 1 & 1 & 1 & 1 & 1 & 1 & 1 & 1 & 1 & 1 & 1 & 1 \\
\hline & 3 & 1 & 1 & 1 & 1 & 1 & 1 & 1 & 1 & 1 & 1 & 1 & 1 & 1 & 1 & 1 \\
\hline & 4 & 1 & 1 & 1 & 1 & 1 & 1 & 1 & 1 & 1 & 1 & 1 & 1 & 1 & 1 & 1 \\
\hline & 5 & 1 & 1 & 1 & 1 & 1 & 1 & 1 & 1 & 1 & 1 & 1 & 1 & 1 & 1 & 1 \\
\hline \multirow{3}{*}{ 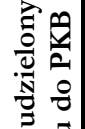 } & 6 & 1 & 1 & 1 & 1 & 1 & 1 & 1 & 1 & 1 & 1 & 1 & 1 & 1 & 1 & 1 \\
\hline & 7 & 1 & 1 & 1 & 1 & 1 & 1 & 1 & 1 & 1 & 1 & 1 & 1 & 1 & 1 & 1 \\
\hline & 8 & 1 & 1 & 1 & 1 & 1 & 1 & 1 & 1 & 1 & 1 & 1 & 1 & 2 & 2 & 2 \\
\hline \multirow{4}{*}{ 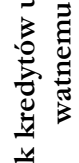 } & 9 & 1 & 1 & 1 & 1 & 1 & 1 & 1 & 1 & 1 & 1 & 2 & 2 & 2 & 3 & 3 \\
\hline & 10 & 1 & 1 & 1 & 1 & 1 & 1 & 1 & 1 & 2 & 2 & 2 & 3 & 3 & 3 & 4 \\
\hline & 11 & 1 & 1 & 1 & 1 & 1 & 2 & 2 & 2 & 2 & 3 & 3 & 3 & 4 & 4 & 4 \\
\hline & 12 & 1 & 1 & 1 & 2 & 2 & 2 & 3 & 3 & 3 & 3 & 4 & 4 & 4 & 5 & 5 \\
\hline \multirow{3}{*}{ 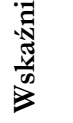 } & 13 & 1 & 2 & 2 & 2 & 3 & 3 & 3 & 4 & 4 & 4 & 4 & 5 & 5 & 5 & 6 \\
\hline & 14 & 2 & 2 & 3 & 3 & 3 & 4 & 4 & 4 & 5 & 5 & 5 & 5 & 6 & 6 & 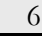 \\
\hline & 15 & 3 & 3 & 3 & 4 & 4 & 4 & 5 & 5 & 5 & 6 & 6 & 6 & 6 & 7 & 7 \\
\hline
\end{tabular}

Źródło: [Rating Methodology..., 2016].

\subsection{Standard\&Poor's Financial Service}

Kolejną agencją ratingowa której metodologia została poddana analizie, była Standard\&Poor's Financial Service. Zgodnie z dotychczasowymi badaniami [Chodnicka, 2014; Chodnicka-Jaworska, 2015a; 2015b; 2015c], to na zmiany not tej agencji rynek jest najbardziej wrażliwy. Możliwość zmiany ratingów kredytowych prowadzi do korekty na rynku kapitałowym od 30 do 180 dni przed zmianą. Najsilniejszą reakcję obserwuje się w ciagu 30 dni przed i po zmianie [Chodnicka-Jaworska 2015a; 2015b]. Dotychczasowe badania biora pod uwage te same czynniki oceny ratingowej dla wszystkich rodzajów ratingu kredytowego. W praktyce poszczególne agencje stosują inne metody estymacji ryzyka upadłości. Standard\&Poor’s Financial Service w swojej metodologii wskazuje na następujące grupy czynników:

- ocenę ryzyka biznesowego: ryzyko ekonomiczne, ryzyko sektora, zarządzanie i strategia, pozycja rynkowa, dywersyfikacja;

- ocenę ryzyka finansowego: analiza sprawozdań finansowych, przychody, elastyczność finansowa, kapitalizacja rynkowa;

- ocenę zarządzania ryzykiem finansowym: rynkowa stopa procentowa, ryzyko kredytowe, ryzyko płynności, ryzyko finansowania.

W tabeli 5. przedstawiono czynniki uwzględniane przy analizie profilu makroekonomicznego banku. Determinanty brane pod uwagę przez Moody's różnią się w porównaniu z tymi prezentowanymi przez S\&P. 
TABELA 5.

Makroekonomiczny profil banku Standard\&Poor's

\begin{tabular}{|c|c|c|}
\hline Czynnik & Sub-czynnik & Wskaźnik \\
\hline \multicolumn{3}{|c|}{ Ryzyko ekonomiczne } \\
\hline $\begin{array}{l}\text { Odporność } \\
\text { gospodarcza }\end{array}$ & $\begin{array}{l}\text { Stabilność i struktura gospodarki } \\
\text { Elastyczność polityki makroekonomicznej } \\
\text { Ryzyko polityczne }\end{array}$ & PKB per capita \\
\hline $\begin{array}{l}\text { Nierównowaga } \\
\text { gospodarcza }\end{array}$ & $\begin{array}{l}\text { Faza ekspansywna } \\
\text { Stopa wzrostu kredytów w sektorze prywatnym } \\
\text { Ceny akcji } \\
\text { Saldo obrotów bieżących i zewnętrzne zadłużenie } \\
\text { lub } \\
\text { Faza korekty } \\
\text { Oczekiwany wpływ sektora bankowego }\end{array}$ & $\begin{array}{l}\text { Nietypowe zmiany stopy } \\
\text { wzrostu kredytów w sek- } \\
\text { torze prywatnym lub cen } \\
\text { akcji } \\
\text { Ceny nieruchomości ko- } \\
\text { mercyjnych }\end{array}$ \\
\hline $\begin{array}{l}\text { Ryzyko kredy- } \\
\text { towe w gospo- } \\
\quad \text { darce }\end{array}$ & $\begin{array}{l}\text { Zdolność kredytowa sektora prywatnego i dźwig- } \\
\text { nia } \\
\text { Standardy pożyczkowe i underwiting } \\
\text { Kultura płatności i regulacje prawne } \\
\text { Zadłużenie zagraniczne kraju }\end{array}$ & $\begin{array}{l}\text { Zmienność cen i zmiany } \\
\text { kursów walut } \\
\text { Specyficzne uwarunko- } \\
\text { wania kraju }\end{array}$ \\
\hline $\begin{array}{l}\text { Ramy instytu- } \\
\text { cjonalne }\end{array}$ & $\begin{array}{l}\text { Regulacje i nadzór nad sektorem bankowym } \\
\text { Błędy regulacyjne } \\
\text { Lad korporacyjny i przejrzystość }\end{array}$ & \\
\hline $\begin{array}{l}\text { Dynamika kon- } \\
\text { kurencyjności }\end{array}$ & $\begin{array}{l}\text { Apetyt na ryzyko } \\
\text { Stabilność sektora } \\
\text { Zakłócenia rynku }\end{array}$ & \\
\hline $\begin{array}{l}\text { System finanso- } \\
\text { wania }\end{array}$ & $\begin{array}{l}\text { Podstawowe depozyty klientów } \\
\text { Finansowanie zewnętrzne } \\
\text { Zadłużenie na krajowym rynków kapitałowym } \\
\text { Rola rządu }\end{array}$ & $\begin{array}{l}\text { Aktywa z wyłączeniem } \\
\text { kredytów }\end{array}$ \\
\hline
\end{tabular}

Źródło: [Standard\&Poor's Rating Services, 2013].

Tak jak w przypadku Moody’s, również S\&P w procesie analizy wykorzystuje metodę scoringowa. Do każdej z analizowanych zmiennych jest stosowana skala od 1 do 6 , gdzie 1 oznacza najniższe ryzyko, a 6 najwyższe. Następnie każda z not otrzymuje skalę punktowa. Klasyfikacja punktowa została zaprezentowana w tabeli 6 .

TABELA 6.

Klasyfikacja punktowa wykorzystywana przez S\&P do analizy ryzyka kraju i banku

\begin{tabular}{|l|c|c|}
\hline Opis ryzyka & Poziom ryzyka & Punkty \\
\hline Bardzo niskie & 1. & 1 \\
Niskie & 2. & 2 \\
Przeciętne & 3. & 3 \\
Wysokie & 4. & 5 \\
Bardzo wysokie & 5. & 7 \\
Ekstremalnie wysokie & 6. & 10 \\
\hline
\end{tabular}

Źródło: [Standard\&Poor's Rating Services, 2013]. 
Po otrzymaniu noty punktowej przypisanej każdej zmiennej są one sumowane i na jej podstawie jest oceniany poziom ryzyka kraju i banku. Im większa liczba punktów, tym wyższe ryzyko. Klasyfikację punktową przedstawiono w tabeli 7.

TABELA 7.

Sumaryczna ocena punktowa wykorzystywana przez S\&P do analizy ryzyka kraju i banku

\begin{tabular}{|c|c|}
\hline Sumaryczna ocena punktowa & Ryzyko ekonomiczne i sektorowe \\
\hline $3-4$ & 1 \\
$5-6$ & 2 \\
$7-8$ & 3 \\
$9-10$ & 4 \\
$11-12$ & 5 \\
$13-14$ & 6 \\
$15-17$ & 7 \\
$18-20$ & 8 \\
$21-23$ & 9 \\
$24-30$ & 10 \\
\hline
\end{tabular}

Źródło: [Standard\&Poor's Rating Services, 2013].

W efekcie powstaje macierz scoringowa pomiędzy ryzykiem sektora a ryzykiem makroekonomicznym. Im większa jest liczba punktów, tym wyższe ryzyko. Macierz scoringową zaprezentowano w tabeli 8 .

TABELA 8.

Macierz scoringowa S\&P do analizy ryzyka kraju i banku

\begin{tabular}{|c|c|c|c|c|c|c|c|c|c|c|c|}
\hline \multicolumn{12}{|c|}{ Ryzyko sektora bankowego } \\
\hline \multirow{11}{*}{ 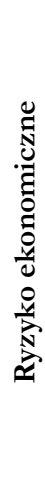 } & & 1 & 2 & 3 & 4 & 5 & 6 & 7 & 8 & 9 & 10 \\
\hline & 1 & 1 & 1 & 2 & 3 & 3 & 4 & & & & \\
\hline & 2 & 1 & 2 & 2 & 3 & 4 & 4 & 5 & & & \\
\hline & 3 & 2 & 2 & 3 & 3 & 4 & 5 & 5 & 6 & & \\
\hline & 4 & 3 & 3 & 3 & 4 & 4 & 5 & 6 & 7 & 7 & \\
\hline & 5 & 3 & 4 & 4 & 4 & 5 & 5 & 6 & 7 & 8 & 9 \\
\hline & 6 & 4 & 4 & 5 & 5 & 5 & 6 & 7 & 7 & 8 & 9 \\
\hline & 7 & & 5 & 5 & 6 & 6 & 7 & 7 & 8 & 8 & 9 \\
\hline & 8 & & & 6 & 7 & 7 & 7 & 8 & 8 & 9 & 10 \\
\hline & 9 & & & & 7 & 8 & 8 & 8 & 9 & 9 & 10 \\
\hline & 10 & & & & & 9 & 9 & 9 & 10 & 10 & 10 \\
\hline
\end{tabular}

Źródło: [Standard\&Poor's Rating Services, 2013]. 


\section{Przegląd badań literaturowych na temat determinant credit ratingów banków}

W dotychczasowych badaniach nie poruszano wyłącznie kwestii wpływu kondycji sektora bankowego na credit rating nadawany poszczególnym bankom. Przeprowadzona powyżej analiza metodologii oceny ryzyka niewypłacalności banku przy uwzględnieniu warunków makroekonomicznych sugeruje, iż istnieje wpływ determinant związanych z rozwojem sektora bankowego na badane zjawisko. Stąd postanowiono dokonać przeglądu literaturowego w zakresie czynników oddziałujących na credit rating danego banku. Problem nie był dotychczas szeroko przebadany, dlatego istnieje zaledwie kilka publikacji odnoszących się do tego zjawiska.

Bissoondoyal-Bheenick i Treepongkaruna [2011] zbadali wpływ poszczególnych grup czynników na credit rating banku określony przez Fitch, Moody's i S\&P. Analizie poddano 69 banków z Wielkiej Brytanii i Australii. Czynniki zostały pogrupowane według: jakości aktywów, ryzyka rynkowego, ryzyka płynności, adekwatności kapitałowej i ryzyka makroekonomicznego. Wśród zmiennych makro do badania wykorzystano jedynie PKB i inflację.

Kolejne badania zostały zaproponowane przez: Hau, Langfield i Marques-Ibanez [2012]. Przeanalizowali oni czynniki, które moga oddziaływać na noty nadawane przez trzy największe agencje ratingowe. Wśród determinant znalazły się: ROA, zlogarytmowana wielkość aktywów, dźwignia finansowa, stosunek kredytów do aktywów, udział zabezpieczeń, depozyty do aktywów, wskaźnik HHI. Wśród zmiennych makroekonomicznych wyróżniono stopę wzrostu kredytów. Również Van Laere i inni [2012] zwrócili uwagę na poziom akcji kredytowej sektora bankowego.

Rojas-Suarez [2001] w swoim badaniu także zwróciła uwagę na wská́nik wzrostu kredytów. Jednak wśród innych czynników wyodrębniono: spread pomiędzy oprocentowaniem kredytów i depozytów, wysokość odsetek od depozytów, stopę wzrostu kredytów międzybankowych. W przedstawionej przez Rojas-Suarez analizie to wspominane czynniki makroekonomiczne powinny determinować rating banku w krajach rozwijających się.

W większości badań analizie poddano wyłącznie wpływ zmiennych wewnętrznych, czyli tych wynikających z analizy wskaźników finansowych, np.: Hassan i Barell [2013], Chodnicka-Jaworska [2016a; 2016b], Bellotti i inni [2011a; 2011b].

\section{Opis danych i metodologia badania}

W zaprezentowanej pracy postanowiono zweryfikować, jak kondycja finansowa sektora bankowego wpływa na noty nadawane bankom przez agencje ratingowe. W związku z tym postawiono następująca hipotezę badawcza: rozwinięty, stabilny i efektywny sektor bankowy pozytywnie oddziałuje na credit rating nadawany poszczególnym bankom. Badanie przeprowadzono dzięki zastosowaniu metod regresji panelowej na danych rocznych dla lat 2005-2015. W badaniu posłużono się danymi rocznymi dla 731 banków 
pochodzących z krajów europejskich ${ }^{1}$, notowanych na giełdach papierów wartościowych. Dane pozyskano z bazy Thomson Reuters Database. Jako noty ratingowe wykorzystano długoterminowe credit ratingi emitenta publikowane przez S\&P i Moody. Z dostępnej autorce wiedzy wynika, że badanie na ten temat nie było dotychczas przeprowadzane.

W analizie posłużono się statycznymi i dynamicznymi modelami panelowymi. Jako zmienne niezależne zastosowano dane dotyczące kondycji sektora bankowego publikowane w bazie Banku Światowego. Listę determinant przedstawiono w tabeli 9. Wśród analizowanych zmiennych znalazły się wskaźniki zaproponowane przez: Beck, Demigurc-Kunt i Levine [2009].

Ostateczna wersja statycznej regresji panelowej została zaprezentowana w równaniu (1), a dynamicznej w równaniu (2):

$$
\begin{gathered}
y_{i, t}=\sum_{k=0}^{n} \beta_{k} x_{j, t-k}+\theta_{t} T_{t}+\mu_{j}+\varepsilon_{j, t}, \\
y_{i, t}=\sum_{k=1}^{n} \alpha_{k} y_{j, t-k}+\sum_{k=0}^{n} \beta_{k} x_{j, t-k}+\theta_{t} T_{t}+\mu_{j}+\varepsilon_{j, t},
\end{gathered}
$$

gdzie:

$y_{i, t}$ to nadawany bankowi długoterminowy rating emitenta nadawany przez Moody's oraz S\&P's, gdzie $i$ to poszczególny bank, a $t$ to dany rok;

$x_{j, t}$ to wektor zmiennych zależnych, gdzie $j$ to poszczególny sektor bankowy, a $t$ to dany rok i tak:

$$
\begin{gathered}
x_{i, j}=\left[\operatorname{pcrdbofgdp}_{j, t}, \text { bdgdp }_{j, t}, \text { dbacba }_{i, j}, \text {,etintmargin }_{i, j}, \text { bcbd }_{j, t},\right. \\
\operatorname{costinc}_{j, t}, \text { overhead }_{i, j}, \text {,oncentration }_{i, j}, \text { rod }_{i, j}, \\
\text { roe } \left._{i, j}, \text { zscore }_{i, j}, \text { offdep }_{i, j}, \text {,intldebtnet }_{i, j}, \text { remit }_{i, j}\right] .
\end{gathered}
$$

Do analizy czynników, mogących wpływać zgodnie ze sprawozdaniami prezentowanymi przez agencje ratingowe, zostały wykorzystane statyczne modele panelowe, tj. modele panelowe ze sztucznymi zmiennymi oraz modele panelowe $z$ dekompozycja składnika losowego. Ze względu na poprawność ekonometryczną w przypadku niemożności zastosowania wspominanych metod badawczych posłużono się regresją liniowa przy użyciu metody najmniejszych kwadratów oraz uogólnionej metody najmniejszych kwadratów. Celem podjęcia decyzji o wyborze pomiędzy modelami z efektami stałymi a modelami z dekompozycją składnika losowego spożytkowano test Hausmana, gdzie zerowa hipoteza zakłada, że efekty grupowe są nieskorelowane ze zmiennymi objaśniającymi, a więc poprawny jest model $z$ dekompozycją składnika losowego [Greene, 2012]. Zastosowano również test mnożnika Lagrange’a zaproponowany przez Breuscha-

${ }^{1}$ Były nimi takie kraje, jak: Albania, Armenia, Austria, Białoruś, Belgia, Bośnia i Hercegowina, Bułgaria, Chorwacja, Cypr, Czechy, Dania, Finlandia, Francja, Gruzja, Niemcy, Grecja, Węgry, Islandia, Irlandia, Włochy, Łotwa, Lichtenstein, Litwa, Luxemburg, Macedonia, Malta, Mołdawia, Monako, Czarnogóra, Holandia, Norwegia, Polska, Portugalia, Rumunia, Rosja, Serbia, Słowacja, Słowenia, Hiszpania, Szwecja, Szwajcaria, Turcja, Ukraina, Wielka Brytania. 
Pagana, który pomaga zdecydować o wyborze pomiędzy modelami z efektami losowymi a regresją liniowa przy użyciu metody najmniejszych kwadratów.

TABELA 9.

\section{Lista zmiennych niezależnych wykorzystanych do badania}

\begin{tabular}{|c|c|}
\hline Nazwa wskaźnika & Skrót \\
\hline \multicolumn{2}{|l|}{ Wskaźnik wielkości sektora finansowego } \\
\hline $\begin{array}{l}\text { Wskaźnik prywatnych kredytów udzielanych przez banki depozytowo-kre- } \\
\text { dytowe i inne instytucje finansowe/PKB }\end{array}$ & pcrdbofgdp \\
\hline \multicolumn{2}{|l|}{ Wskaźniki wielkości sektora bankowego } \\
\hline Wskaźnik depozytów banków komercyjnych/PKB & bdgdp \\
\hline Wskaźnik aktywów banków depozytowych/aktywa sektora bankowego & dbacba \\
\hline \multicolumn{2}{|l|}{ Wskaźniki efektywności sektora bankowego } \\
\hline Marża odsetkowa netto & netintmargin \\
\hline Wskaźnik kosztów ogólnych & overhead \\
\hline Wskaźnik kredytów do depozytów & bcbd \\
\hline Wskaźnik kosztów ogólnych do przychodów brutto & costinc \\
\hline \multicolumn{2}{|l|}{ Wskaźnik struktury sektora bankowego } \\
\hline Wskaźnik koncentracji & concentration \\
\hline \multicolumn{2}{|l|}{ Wskaźniki zyskowności sektora bankowego } \\
\hline $\mathrm{ROA}$ & roa \\
\hline ROE & roe \\
\hline \multicolumn{2}{|l|}{ Wskaźnik stabilności sektora bankowego } \\
\hline Wskaźnik - z & zscore \\
\hline \multicolumn{2}{|l|}{ Wskaźniki globalizacji sektora bankowego } \\
\hline $\begin{array}{l}\text { Wskaźnik depozytów banków z krajów offshore /depozytów utrzymywanych } \\
\text { w bankach krajowych }\end{array}$ & offdep \\
\hline Wskaźnik przepływów środków pieniężnych/PKB & intldebtnet \\
\hline Wskaźnik międzynarodowych pożyczek od banków nierezydentów/PKB & remit \\
\hline
\end{tabular}

Źródło: opracowanie własne; klasyfikacja za: [Beck, Demigurc-Kunt, Levine, 2009].

Dodatkowo postanowiono zweryfikować wpływ opóźnień czasowych na analizowaną zmienną. Ze względu na obecność danych czasowo-przestrzennych wykorzystano metody estymacji dynamicznych modeli panelowych. Pierwszym z nich był jednostopniowy estymator Arellano i Bonda ze zmienną zależną na dwóch opóźnieniach. Jakość modelu zaproponowanego przez Arellano i Bonda zależy od istotności użytych w nim instrumentów. Do analizy poprawności modelu zastosowano test Sargana, który służy badaniu obecności heteroskedastyczności składnika losowego. Hipoteza zerowa mówi, iż wykorzystane instrumenty są właściwe w sensie ich nieskorelowania ze składnikami losowymi modelu pierwszych różnic. W przypadku odrzucenia hipotezy zerowej stosowano model z korektą heteroskedastyczności. Drugim testem był test autokorelacji Arellano-Bonda. Występowanie autokorelacji pierwszego rzędu w modelu pierwszych różnic było zjawiskiem spodziewanym z uwagi na niezależność składnika losowego. Występowanie autokorelacji rzędu wyższego niż jeden oznaczałoby, że instrumenty użyte podczas estymacji GMM nie były właściwe. Weryfikowana była hipoteza zerowa o niewystępowaniu autokorelacji drugiego rzędu w modelu. 
W badaniu posłużono się liniową metodą dekompozycji credit ratingów, którą przedstawiono w tabeli 10 .

TABELA 10.

Liniowa metoda dekompozycji credit ratingów

\begin{tabular}{|c|c|c|c|}
\hline \multicolumn{2}{|c|}{ Moody's Long-term Issuer Rating } & \multicolumn{2}{|c|}{ S\&P's Long-term Issuer Rating } \\
\hline Rating & Kod & Rating & Kod \\
\hline Aaa & 100 & $\mathrm{AAA}$ & 100 \\
\hline Aa1 & 95 & $\mathrm{AA}+$ & 95 \\
\hline $\mathrm{Aa} 2$ & 90 & $\mathrm{AA}$ & 90 \\
\hline Aa3 & 85 & AA- & 85 \\
\hline A1 & 80 & $\mathrm{~A}+$ & 80 \\
\hline A2 & 75 & A & 75 \\
\hline A3 & 70 & A- & 70 \\
\hline Baa1 & 65 & $\mathrm{BBB}+$ & 65 \\
\hline Baa2 & 60 & $\mathrm{BBB}$ & 60 \\
\hline Baa3 & 55 & BBB- & 55 \\
\hline $\mathrm{Ba} 1$ & 50 & $\mathrm{BB}+$ & 50 \\
\hline $\mathrm{Ba} 2$ & 45 & $\mathrm{BB}$ & 45 \\
\hline $\mathrm{Ba} 3$ & 40 & BB- & 40 \\
\hline B1 & 35 & $\mathrm{~B}+$ & 35 \\
\hline B2 & 30 & B & 30 \\
\hline B3 & 25 & B- & 25 \\
\hline Caa1 & 20 & $\mathrm{CCC}+$ & 20 \\
\hline $\mathrm{Caa} 2$ & 15 & CCC & 15 \\
\hline $\mathrm{Caa} 3$ & 10 & CCC- & 10 \\
\hline Caa & 5 & CC & 5 \\
\hline C & 0 & NR & 0 \\
\hline WR & -5 & SD & -5 \\
\hline
\end{tabular}

Źródło: opracowanie własne.

\section{Analiza wpływu sektora bankowego na rating kredytowy banków}

Badanie wpływu kondycji sektora bankowego na credit rating poszczególnych banków europejskich rozpoczęto od analizy podstawowych statystyk opisowych, których wyniki zaprezentowano w załączniku 1. Następnie zweryfikowano współczynniki korelacji Spearmana. W związku ze zróżnicowaniem próby wykonano oddzielne obliczenia dla banków, które otrzymały noty od S\&P i Moody. Wyniki przedstawiono w załączniku 2.

Z kolei zweryfikowano wpływ poszczególnych zmiennych świadczących o kondycji i wielkości sektora bankowego na rating banku. Oddzielnie wykonano obliczenia dla dwóch analizowanych agencji. Pierwsza grupą wskaźników poddanych analizie był wskaźnik wielkości sektora finansowego, mierzony stosunkiem udzielanych kredytów do PKB. Wraz ze wzrostem analizowanej zmiennej credit rating banku zaproponowany przez Moody i S\&P poprawia się o 0,25 jednostki. Badana zmienna wpływa na rating S\&P również 
z opóźnieniem czasowym, lecz jej kierunek nie jest jednolity. Rozwinięty sektor finansowy przyczynia się do wzrostu poziomu gospodarczego danego kraju, a tym samym oddziałuje na uwarunkowania ekonomiczne, w jakich funkcjonuje dany bank.

Kolejna grupą czynników była wielkość samego sektora bankowego. Wysoki udział aktywów banków depozytowych w aktywach sektora wpływa niekorzystnie na notę ratingową nadawana przez S\&P i Moody. Analizowana zależność ma miejsce z opóźnieniem czasowym i jest silniejsza w przypadku not nadawanych przez Moody. Jest to wynik działalności inwestycyjnej, jaką podejmują banki komercyjne. Drugim z badanych czynników był stosunek poziomu depozytów do PKB. Zmienna oddziałuje negatywnie na noty nadawane przez S\&P. Jednak należy podkreślić, iż wysoki poziom depozytów jest korzystny pod względem bezpieczeństwa finansowania banku w krótkim okresie, ale przy długoterminowym utrzymywaniu się prowadzi do zagrożenia ryzyka płynności i wzrostu kosztów finansowania, na co wskazuje początkowo pozytywna zależność, która wraz z upływem czasu zmienia kierunek.

Kolejną grupą czynników poddaną badaniu były wskaźniki efektywności. Istotny statystycznie wpływ na poziom credit ratingu banku wywiera stosunek kredytów do pozyskanych depozytów. Badana zmienna wpływa na credit rating z opóźnieniem czasowym w sposób pozytywny. Im większy udział kredytów, tym wyższe dochody. Badana zależność jest silniejsza w przypadku Moody. Wskaźnik kosztów ogólnych wpływa w sposób negatywny z opóźnieniem czasowym na noty nadawane przez Moody. Analizowana zależność jest bardzo silna. Na wspominane noty także bardzo silnie oddziałuje poziom marży odsetkowej netto. Jednakże badana zmienna negatywnie oddziałuje na rating również z opóźnieniem czasowym w przypadku S\&P. Poziom kosztów w stosunku do przychodów znacząco wpływa na noty nadawane przez Moody. Wraz ze wzrostem analizowanej zmiennej o 1, rating banku rośnie o 0,4.

Następnie zbadano, jak na rating banku oddziałuje poziom koncentracji sektora bankowego. Istotność analizowanej zmiennej podkreślano w metodologii prezentowanej przez Moody. Badany związek nie jest jednoznaczny. Okazuje, że w przypadku Moody wraz ze wzrostem analizowanej zmiennej credit rating banku poprawa się. Standard\&Poor's Financial Service zaś upatruje w wysokiej koncentracji ryzyko dla bezpieczeństwa całego sektora. Upadek bowiem dużego banku rodzi efekt zakażania się na mniejsze instytucje.

Zyskowność sektora mierzona rentownością aktywów i kapitału własnego również odgrywa zasadniczą rolę w ocenie ryzyka banków. Im większa wartość analizowanych zmiennych, tym lepszy rating. Silniejszy pozytywny związek obserwuje się odniesieniu do not nadawanych przez Moody. Podobna zależność ma miejsce w stosunku do wskaźnika z-score. Im bardziej stabilny sektor, tym mniejsze ryzyko z perspektywy poszczególnego banku. Tak jak poprzednio, równocześnie w tej sytuacji bardziej wrażliwy na analizowaną zmienną jest rating proponowany przez Moody. 
TABELA 11. Analiza wpływu sektora bankowego na rating kredytowy banków europejskich przy wykorzystaniu metod regresji panelowej

\begin{tabular}{|c|c|c|c|c|c|c|c|c|}
\hline \multirow{3}{*}{ Rating } & \multicolumn{4}{|c|}{ Moody's long term issuer rating } & \multicolumn{4}{|c|}{ S\&P long term issuer rating } \\
\hline & \multicolumn{2}{|c|}{ Efekty zmienne } & \multicolumn{2}{|c|}{ Arellano-Bond } & \multicolumn{2}{|c|}{ Efekty stałe } & \multicolumn{2}{|c|}{ Arellano-Bond } \\
\hline & Coef. & $P>t$ & Coef. & $\mathbf{P}>\mathrm{Z}$ & Coef. & $P>t$ & Coef. & $\mathbf{P}>\mathrm{z}$ \\
\hline \multicolumn{9}{|l|}{ rating } \\
\hline L1. & & & .5656285 & 0.000 & & & .5544989 & 0.000 \\
\hline $\mathrm{L} 2$. & & & -.1484179 & 0.058 & & & .0042145 & 0.897 \\
\hline dbacba & .0966015 & 0.625 & .1110853 & 0.870 & .0963987 & 0.489 & .4349612 & 0.087 \\
\hline L1. & & & -1.783046 & 0.022 & & & -.3891465 & 0.182 \\
\hline $\mathrm{L} 2$. & & & .1831721 & 0.786 & & & -.7207647 & 0.017 \\
\hline pcrdbofgdp & .2476354 & 0.000 & -.433392 & 0.253 & .2653999 & 0.000 & -.6573406 & 0.002 \\
\hline L1. & & & .2937301 & 0.678 & & & 1.206061 & 0.000 \\
\hline $\mathrm{L} 2$. & & & -.1677005 & 0.740 & & & -.8041012 & 0.000 \\
\hline bdgdp & -.0743782 & 0.283 & .4077763 & 0.257 & -.4006548 & 0.000 & -.1979268 & 0.343 \\
\hline L1. & & & .1091737 & 0.857 & & & -1.12357 & 0.000 \\
\hline $\mathrm{L} 2$. & & & -.1503321 & 0.752 & & & .9932598 & 0.002 \\
\hline bcbd & -.0171771 & 0.446 & .6179528 & 0.014 & -.0028339 & 0.941 & .0586571 & 0.544 \\
\hline L1. & & & .6802954 & 0.027 & & & -.4926272 & 0.000 \\
\hline $\mathrm{L} 2$. & & & .0976044 & 0.627 & & & .2277663 & 0.017 \\
\hline overhead & -.7769575 & 0.740 & -14.98881 & 0.138 & .0494133 & 0.479 & .1925702 & 0.001 \\
\hline & & & 13.05925 & 0.216 & & & -.0783952 & 0.046 \\
\hline L2. & & & -14.47612 & 0.016 & & & .1439331 & 0.001 \\
\hline netintmargin & -6.264359 & 0.002 & 3.081034 & 0.686 & -1.448914 & 0.034 & -.4497194 & 0.537 \\
\hline & & & -10.4702 & 0.189 & & & -3.416968 & 0.003 \\
\hline & & & 4.215626 & 0.462 & & & -3.081108 & 0.001 \\
\hline concentration & -.0119806 & 0.913 & -.7498849 & 0.112 & -.1685105 & 0.034 & -.4999936 & 0.030 \\
\hline & & & .7265563 & 0.061 & & & -.0276351 & 0.888 \\
\hline $\mathrm{L} 2$. & & & -.6317504 & 0.132 & & & -.0297871 & 0.852 \\
\hline roa & 10.62798 & 0.001 & -6.607057 & 0.237 & .3885831 & 0.001 & .4244289 & 0.035 \\
\hline L1. & & & 3.192709 & 0.727 & & & -1.056347 & 0.095 \\
\hline $\mathrm{L} 2$. & & & -.9246327 & 0.915 & & & 1.926717 & 0.003 \\
\hline roe & -.33104 & 0.058 & .7924397 & 0.042 & -.03269 & 0.217 & -.311529 & 0.023 \\
\hline L1. & & & -.2105131 & 0.621 & & & .4060498 & 0.009 \\
\hline $\mathrm{L} 2$. & & & .5544469 & 0.175 & & & .1419549 & 0.097 \\
\hline costinc & .3089983 & 0.000 & .4200972 & 0.075 & .0005781 & 0.986 & -.0737723 & 0.168 \\
\hline & & & -.1445103 & 0.298 & & & .008395 & 0.877 \\
\hline $\mathrm{L} 2$. & & & .3074779 & 0.014 & & & -.0339107 & 0.516 \\
\hline z-score & -.1111742 & 0.692 & 1.640588 & 0.041 & .3221074 & 0.079 & .4507682 & 0.251 \\
\hline L1. & & & -.7761045 & 0.398 & & & -1.181464 & 0.023 \\
\hline L2. & & & -.5325856 & 0.397 & & & -1.930023 & 0.000 \\
\hline intldebtnet & 1.790664 & 0.006 & -1.652654 & 0.208 & -.7836653 & 0.040 & -.1694282 & 0.632 \\
\hline & & & 1.06007 & 0.428 & & & -.7235029 & 0.162 \\
\hline $\mathrm{L} 2$. & & & 1.837128 & 0.045 & & & .1809161 & 0.740 \\
\hline offdep & -.153262 & 0.159 & -1.496155 & 0.006 & -.3956996 & 0.000 & -.136085 & 0.521 \\
\hline L1. & & & .598488 & 0.251 & & & -.6869881 & 0.017 \\
\hline $\mathrm{L} 2$. & & & .3878607 & 0.570 & & & .6351989 & 0.090 \\
\hline remit & -3.213936 & 0.026 & 2.066965 & 0.593 & 4.513016 & 0.010 & 8.07538 & 0.069 \\
\hline L1. & & & 24.85441 & 0.049 & & & 8.223819 & 0.006 \\
\hline $\mathrm{L} 2$. & & & -1.783378 & 0.655 & & & 4.255846 & 0.154 \\
\hline _cons & 23.82177 & 0.335 & 70.99266 & 0.587 & 51.12044 & 0.003 & 254.4392 & 0.000 \\
\hline no obs & \multicolumn{2}{|c|}{533} & \multicolumn{2}{|c|}{281} & \multicolumn{2}{|c|}{1787} & \multicolumn{2}{|c|}{960} \\
\hline no group & \multicolumn{2}{|c|}{87} & \multicolumn{2}{|c|}{73} & \multicolumn{2}{|c|}{283} & \multicolumn{2}{|c|}{252} \\
\hline Wald & 0.0 & & & & & & 0.0 & \\
\hline Hausman & 0.4 & & & & & & & \\
\hline Breusch-Pagan & 0.0 & & & & & & & \\
\hline Sargan & & & & & & & 0.0 & \\
\hline $\mathrm{AB}(1)$ & & & & & & & 0.0 & \\
\hline $\mathrm{AB}(2)$ & & & & & & & 0.4 & \\
\hline Typ & $\mathrm{R}$ & & one & & & & one & \\
\hline
\end{tabular}

Źródło: opracowanie własne. 
Ostatnia grupą determinant poddaną weryfikacji były czynniki związane z globalizacją sektora bankowego. Wśród analizowanych zmiennych badano: wpływ stosunku depozytów banków z krajów offshore do łącznych depozytów, wskaźnik przepływów środków pieniężnych do PKB oraz wskaźnik międzynarodowych pożyczek od banków nierezydentów do PKB. Analogicznie jak wcześniej, i w tym przypadku upatruje się różnych związków pomiędzy analizowaną zmienną a notami proponowanymi przez poszczególne agencje ratingowe. Okazuje się, że im wyższy udział przepływów pieniężnych do PKB, tym wyższy rating proponowany przez Moody. Wzrost wskaźnika powoduje podwyżkę ratingu o 1,8. Rating reaguje zarówno na zmiany w bieżącym okresie, jak i dwa lata wcześniej. Natomiast wysoki udział badanego wskaźnika S\&P traktuje jako niebezpieczeństwo z powodu możliwości odpływu kapitału za granicę. W efekcie wraz ze wzrostem wskaźnika o 1, rating kraju spada w bieżącym okresie o około 0,8. Stosunek depozytów z krajów offshore do łącznych depozytów wywiera negatywny wpływ na rating banku. Moody silniej reaguje na badaną zmienna, zwłaszcza w bieżącym roku, tymczasem S\&P z opóźnieniem czasowym. Negatywny wpływ analizowanej zmiennej wynika $z$ obawy przed niestabilnymi depozytami z rajów podatkowych. Tymczasem finansowanie kapitałem zagranicznym ze spółek matek pozytywnie oddziałuje na rating banku. Badana zmienna jest szczególnie istotna w odniesieniu do not nadawanych przez Moody.

\section{Podsumowanie}

Celem tego artykułu była weryfikacja, jak kondycja finansowa sektora bankowego wpływa na noty nadawane bankom przez agencje ratingowe. W związku z tym postawiono następującą hipotezę badawczą: rozwinięty, stabilny i efektywny sektor bankowy pozytywnie oddziałuje na credit rating otrzymywany przez poszczególne banki. Analiza metodologii wykorzystywanej przez agencje ratingowe sugeruje, że przy badaniu ryzyka banków uwzględnia się kondycję sektora bankowego. Moody w swojej ocenie bierze pod uwagę stopę wzrostu kredytów oraz koncentrację mierzoną indeksem HHI. Ponadto, analizuje spread pomiędzy oprocentowaniem kredytów a depozytów. W tej analizie zastosowano wskaźniki ryzyka proponowane przez Beck, Demirgüç-Kunt i Levine. Zweryfikowano wpływ: wielkości sektora finansowego, sektora bankowego, jego efektywności, koncentracji, stabilności i globalizacji. Ze względu na występowanie korelacji wybrano tylko niektóre z parametrów. Przeprowadzone badanie świadczy o tym, że rating kredytowy banku jest ściśle uzależniony od kondycji całego sektora. Okazuje się, że badane zmienne mają wpływ zarówno w roku bieżącym, jak i z opóźnieniem czasowym. Warto zatem podkreślić, że wraz ze wzrostem: sektora finansowego i bankowego, jego stabilności, zyskowności i efektywności, credit rating banku ulega poprawie. Natomiast wysoki poziom koncentracji sektora i globalizacji rynku nie wpływa w sposób korzystny na noty nadawane bankom. W pierwszym przypadku jest to wynik możliwości pojawienia się zjawiska zakażania pomiędzy instytucjami finansowymi. Wysoki poziom globalizacji prowadzi do łatwego odpływu kapitału za granicę. Pozytywnie zaś należy odnieść się do możliwości wsparcia banków przez zagraniczne spółki matki. 
Przeprowadzone badanie dowodzi, że występują rozmaite zależności pomiędzy poszczególnymi zmiennymi a ratingiem nadanym bankom przez agencje. Bowiem agencje ratingowe z różnym opóźnieniem czasowym reagują na zmiany analizowanych wskaźników. Ponadto, wykorzystują inne związki przyczynowo-skutkowe podczas procesu oceny, które stanowią dalszy przedmiot badań prowadzonych przez autorkę.

\section{Literatura}

Beck T., Demirgüç-Kunt A., Levine R., 2009, Financial Institutions and Markets Across Countries and over Time: Data and Analysis, "World Bank Policy Research Working Paper", no. 4943.

Bellotti T., Matousek R., Stewart C., 2011a, A note comparing support vector machines and ordered choice models' predictions of international banks' rating, "Decision Support Systems", no. 51(3), June.

Bellotti T., Matousek R., Stewart C., 2011b, Are rating agencies' assignments opaque? Evidence from international banks, "Expert Systems with Applications", no. 38(4), April.

Bissoondoyal-Bheenick E., Treepongkaruna S., 2011, An analysis of the determinants of bank ratings: comparison across ratings agencies, "Australian Journal of Management", vol. 36, no. 3, p. 405-424, DOI 10.1177/0312896211426676.

Chodnicka-Jaworska P., 2015, Credit Rating Determinants for European Countries, "Global Journal of Management and Business", no. 15(9-C).

Chodnicka-Jaworska P., 2015a, Wpkyw zmian credit ratingów na rynek CDS w krajach europejskich - event study (w druku).

Chodnicka-Jaworska P., 2015b, Information value of the credit rating on the credit default swaps market ( $\mathrm{w}$ druku).

Chodnicka-Jaworska P., 2016a, Banks credit ratings - is the size of the credit rating agency important? (w druku).

Chodnicka-Jaworska P., 2016b, Macroeconomic aspects of banks' credit ratings (w druku).

Greene W. H., 2012, Econometric analysis, Wydanie VII, Pearson, Essex.

Hassan O. A. G, Barrell R., 2013, Accounting for the determinants of banks' credit ratings, "Brunel University of London Economics and Finance Working Paper Series", no. 13-02.

Hau H., Langfield S., Marques-Ibanez D., 2012, Banks ratings what determines their quality?, "European Central Bank Working Paper", no. 1485.

Poon W., Lee J., Gup B.E., 2009, Do solicitations matter in bank credit ratings? Results from a study of 72 countries, "Journal of Money, Credit and Banking", no. 41.

Rating Methodology. Sovereign Bond Ratings, 2013, Moody's Investors Service.

Rating Methodology. Sovereign Bond Ratings, 2015, Moody's Investors Service.

Rating Methodology. Banks, 2016, Moody's Investors Service.

Rojas-Suarez L., 2001, Rating Banks In Emerging Markets: What Credit Rating Agencies Should Learn From Financial Indicators, "Institute for International Economics Working Paper", no. 01-06. 
Shen C., Huang Y., Hasan I., 2012, Asymmetric benchmarking in bank credit rating, "Journal of International Financial Markets, Institutions \& Money", no. 22, 171-193.

Standard \& Poor's Rating Services, 2013, Banking Industry Country Risk Assessment Methodology and Assumptions.

Van Laere E., Vantieghem J., Baesens B., 2012, The difference between Moody's and S\&P bank ratings: is discretion in the rating process causing a split?, "RMI Working Paper", no. 12/05.

Statystyki opisowe

ZALĄCZNIK 1.

\begin{tabular}{|l|c|r|r|r|r|}
\hline \multicolumn{1}{|c|}{ Zmienna } & Obs & Średnia & Od. St. & \multicolumn{1}{c|}{ Min } & \multicolumn{1}{c|}{ Max } \\
\hline Moody & 1287 & 55,33411 & 34,17156 & -5 & 100 \\
S\&P & 4081 & 51,75202 & 30,26445 & -5 & 100 \\
dbacba & 2178 & 94,45229 & 6,116992 & 68,79 & 100 \\
pcrdbofgdp & 2374 & 116,9181 & 62,2261 & 10,25 & 237,58 \\
bdgdp & 2362 & 85,89495 & 59,98828 & 11,99 & 302,74 \\
netintmargin & 2506 & 2,876045 & 1,634235 &, 01 & 15,3 \\
overhead & 2506 & 2,755096 & 5,907438 &, 02 & 90,26 \\
bcbd & 2362 & 115,093 & 85,19176 & 47,13 & 898,05 \\
costinc & 2504 & 56,36114 & 17,81735 & 1,53 & 226,32 \\
concentrat $\sim \mathrm{n}$ & 2476 & 56,83122 & 19,3805 & 22,17 & 100 \\
roa & 2506 &, 7816121 & 3,58686 & $-51,41$ & 20,83 \\
roe & 2506 & 11,45944 & 17,43668 & $-102,89$ & 240,64 \\
z-score & 2506 & 16,49911 & 9,35836 & $-4,55$ & 58,71 \\
offdep & 2385 & 13,22387 & 15,70358 &, 82 & 201,1 \\
remit & 2293 & 1,073384 & 2,352372 & 0 & 13,16 \\
intldebtnet & 2336 &, 5673844 & 1,715555 & $-6,2$ & 16,83 \\
\hline
\end{tabular}

Źródło: opracowanie własne. 


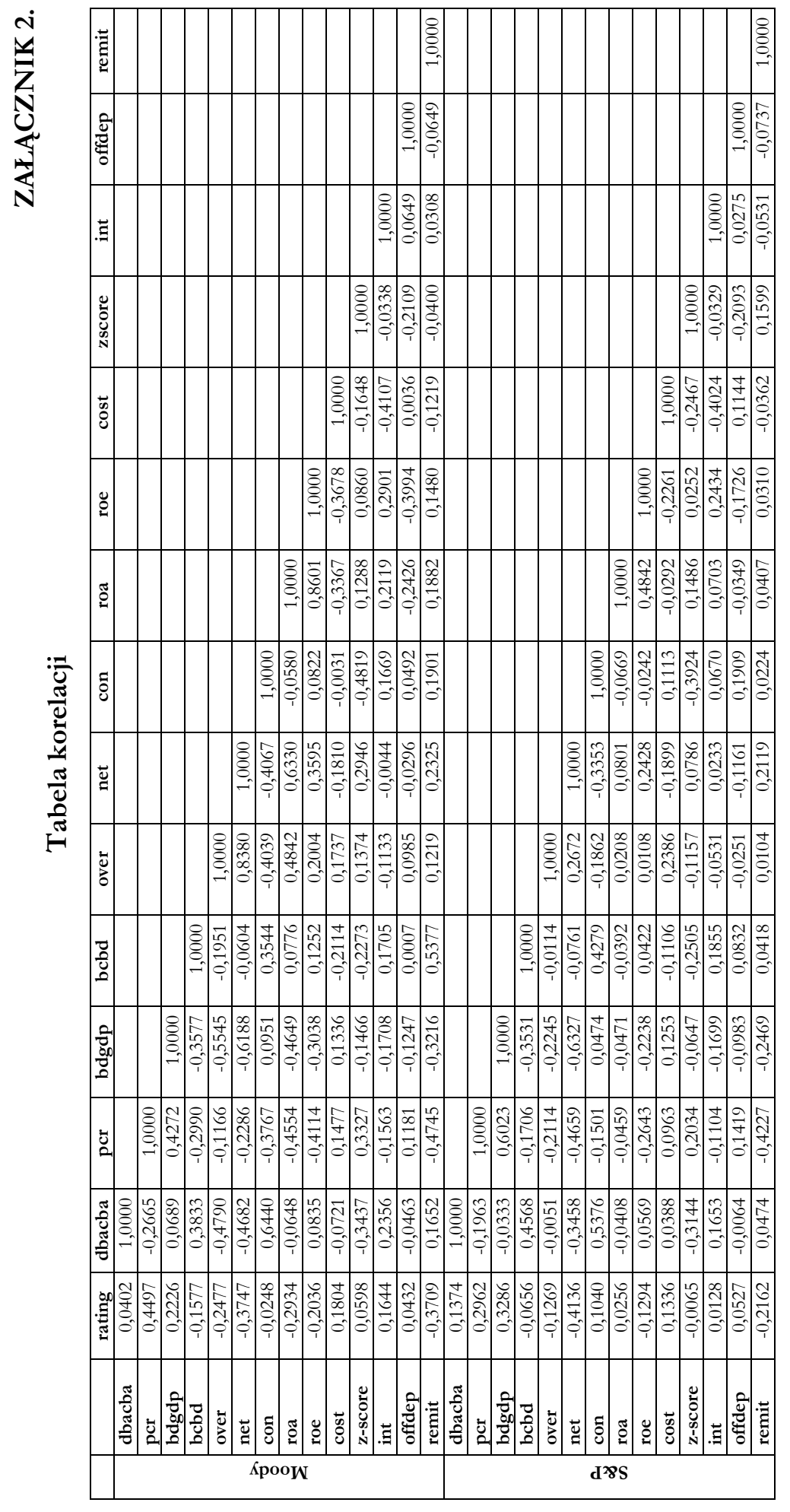

